\title{
Analysis of Risk Factors for Type 2 Diabetes Mellitus From Rural and Urban Areas in Kendari General Hospital, Indonesia
}

\author{
Laode Muhamad Sety ${ }^{1}$, Muhammad Nur Muslim Shidiq ${ }^{2}$ \\ \{setyuho@gmail.com ${ }^{1}$, muhammadnurmuslim05@gmail.com ${ }^{2}$ \} \\ 1,2 Faculty of Public Health, Halu Oleo University, Kendari, Indonesia
}

\begin{abstract}
Diabetes is one of four diseases that are the main killers in the world today, causing serious damage to many body systems, especially nerves and blood vessels. This study aimed to analyze the risk factors for sleep quality and sport activity against the incidence of type 2 diabetes mellitus in patients from urban and rural areas who visited the Kendari City General Hospital in 2018. The research design is a case control study. The sample was 281 people taken by simple random sampling (68 DM cases and 68 cases non DM). The result show that sleep quality and sport activity are risk factors for the incidence of type 2 diabetes mellitus in both urban and rural patients. People are expected to exercise regularly and maintain sleep quality.
\end{abstract}

Keywords: Type 2 Diabetes Mellitus, Sleep Quality, Sports Activities

\section{Introduction}

Non-communicable diseases (NCD) also known as chronic diseases, tend to last a long time and are the result of a combination of genetic, physiological, environmental and behavioral factors. NCD kills 41 million people every year, equivalent to $71 \%$ of all deaths globally. Every year, 15 million people die from PTM between the ages of 30 and 69 years, more than $85 \%$ of these "premature" deaths occur in low and middle income countries [1].

There are four main types of non-communicable diseases, cardiovascular disease, cancer, respiratory diseases and diabetes. The four groups of diseases cover more than $80 \%$ of all NCD deaths. Diabetes is one of the non-communicable diseases with 1.6 million cases each year [2],[3].

Diabetes is a chronic disease that occurs when the pancreas does not produce enough insulin or when the body cannot effectively use the insulin it produces. Insulin is a hormone that regulates blood sugar. Hyperglycemia, or an increase in blood sugar, is a common effect of uncontrolled diabetes and over time causes serious damage to many body systems, especially nerves and blood vessels [1].

The 8th edition of the International Diabetes Federation [4] Atlas in 2017 shows that the estimated number of diabetics ( $20-79$ years) every 1000 population in the world is $424,877.1$ and is expected to increase to 628,663.5 in 2045. The Western Pacific Region comprises from several countries in it (including Indonesia), it has an estimate of diabetics (20-79 years) every 1000 population is $158,757.8$ and is expected to increase to $183,311.6$ in 2045 [4].

Estimates of diabetes (20-79 years) in Indonesia in 2017 are $6.2 \%$ and are expected to increase to $7.4 \%$ in 2045 . In 2017 , the number of diabetics every 1000 population is $10,276.1$ but is expected to increase to $16,650,5$ in 2045 . The number of deaths due to diabetes every 
1000 population in 2017 is 114.1 while the proportion of deaths due to diabetes in people under the age of 60 is $55.8 \%$ [4].

Based on Basic Health Research in 2013, DM is one of the five main non-communicable diseases in Indonesia, with a prevalence of $1.5 \%$. The provinces that have the highest prevalence are Yogyakarta $(2.6 \%)$, the lowest in Lampung $(0.7 \%)$, while those in Southeast Sulawesi Province are $1.1 \%$ [5]. In 2017 the prevalence of DM increased by $2.8 \%$, the highest prevalence of the DKI Jakarta province, the lowest East Nusa Tenggara (NTT) $0.9 \%$. Southeast Sulawesi increased by $1.3 \%$ [6]. In the same time, DM was ranked 5th out of 10 major diseases with 2,436 cases [7], while the city of Kendari is 1,353 cases [8].

Type 2 Diabetes Mellitus is one of several types of diabetes that most often appear in recent times. Type $2 \mathrm{DM}$ is caused by two things, namely insulin resistance and impaired pancreatic beta cell function. Many factors influence the incidence of diabetes mellitus both in terms of environment (diet, stress, socio-economic, cultural, residential area), behavior (obesity, sports activities, drinking alcoholic beverages, sleep quality), genetics (family history, age , sex) or health services (examination of blood sugar levels) [1].

Some people with diabetes mellitus will experience sleep disorders at night. Not infrequently, this event makes them not excited, weak and always sleepy during the day. This disorder is generally felt as a difficulty in sleeping, unable to maintain sleep for a long time, or too long to sleep. These three things can be caused by blood sugar levels that are too high or too low [1]. Sports are important for human health. Even though currently running or going to the gym has become a contemporary lifestyle, in fact the trend of physical activity or exercise throughout the world is decreasing. This fact was revealed by the World Health Organization WHO. Based on WHO recommendations, adults are encouraged to at least exercise or do 150 minutes of physical activity with moderate intensity or 75 minutes with high intensity every week. People who do not meet these conditions are at higher risk of cardiovascular disease, type two diabetes, dementia and some types of cancer [2].

The results of basic health research in 2013 showed the prevalence of diabetes mellitus in residents aged $\geq 15$ years according to residential characteristics namely urban at $2.0 \%$ while rural at $1.0 \%$. The results of basic health research in 2018 showed an increase in the prevalence of diabetes mellitus in residents aged $\geq 15$ years according to the characteristics of the residence, namely urban areas of $10.6 \%$ while the rural areas were $11.2 \%$ [6].

Kendari Regional General Hospital is one of the referral center hospitals in Southeast Sulawesi. In 2018 the patient morbidity (outpatient and inpatient) of Diabetes Mellitus was 801 people, with the highest age> 15 years in Southeast Sulawesi [8]. This study aims to analyze the risk factors for the incidence of Type 2 Diabetes Mellitus in urban and rural patients who visit the Kendari City General Hospital in 2018

\section{Research Method}

The study design used a 1:1 case control study. The population is all patients who examined themselves at the Internal Medicine Poly in Kendari Municipality Hospital from January to September 2018, which was 801 people.

Large numbers of non categorized samples [9] Type I error $(\propto) 5 \%$, power $(\beta) 20 \%$, proportion of previous Diabetes Type 2 events (P2) 0.35 [10]. A sample of 136 people, from urban areas 64 people (34 cases: 34 control) and from rural areas 64 people (34 cases; 34 controls). Sample selection by simple random sampling uses random tables.

The research instrument was a questionnaire containing questions related to the variables studied, including socio demographic features, stress using Depression, Anxiety and Stress 
Scale (DASS 42) [11], sleep quality using the Pittsburgh Sleep Quality Index (PSQI) and sports activities using the Baecke Questionnaire [12],[13].

The study was assisted by a sixth semester student assistant who was trained first. Data inputted using Epi Info Program version 6.2, then converted to SPSS version 20 for further analysis. The form of the respondent's approval in the research by signing the Informed Consent first. However, before being given an explanation to the respondents that confidentiality would be guaranteed and only for research purposes.

\section{Results}

\section{a. Socio demographic characteristics}

Socio demographic description in table 1 shows that from a total of 68 respondents from urban areas, the majority of respondents aged 56-65 years were 30 people $(44.1 \%)$, at least 26-35 years old, 6 people $(8.8 \%)$. Female sex is more dominant, namely 37 people $(54.4 \%)$, compared to men, namely 31 people $(45.6 \%)$. Based on education, most of them have graduated from Higher Education as many as 29 people $(42.6 \%)$ while those with the least number are not in school, namely 1 person $(1.5 \%)$. Based on work, most of them are housewives, namely 25 people $(36.8 \%)$ and the smallest are farmers, namely 1 person $(1.5 \%)$.

In table 2 shows that out of a total of 68 respondents from rural areas, the majority of respondents aged 56-65 years were 29 people $(29.4 \%)$ while the smallest were 26-35 years old, 3 people (4.4\%). Based on gender, there are generally 40 men $(58.8 \%)$. Based on education, most of them graduated from high school as many as 30 people $(44.1 \%)$ and at least not in school, namely 1 person $(1.5 \%)$. The types of work of respondents are generally housewives, namely 20 people $(29.4 \%)$ while the least are fishermen, 2 people $(2.9 \%)$.

Table 1. Socio-demographic characteristics of study participants in Kendari Municipality General Hospital From Urban Area South East Sulawesi Indonesia, 2018.

\begin{tabular}{llccc}
\hline & Characteristics & Cases $(\%)$ & Controls $(\%)$ & Total $(\%)$ \\
\hline Age & $26-35$ & $1(2.9)$ & $5(14.7)$ & $6(8.8)$ \\
& $36-45$ & $3(8.8)$ & $6(17.6)$ & $9(13.2)$ \\
& $46-55$ & $8(23.5)$ & $5(14.7)$ & $13(19.1)$ \\
& $56-65$ & $16(47.1)$ & $14(41.2)$ & $30(44.1)$ \\
Sex & 65 & $6(17.6)$ & $4(11.8)$ & $10(14.7)$ \\
Educational status & Male & $15(44.1)$ & $16(47.1)$ & $31(45.6)$ \\
& Female & $19(55.9)$ & $18(52.9)$ & $37(54.4)$ \\
& No School & $0(0)$ & $1(2.9)$ & $1(1.5)$ \\
& Do not finish primary school & $2(5.9)$ & $0(0)$ & $2(2.9)$ \\
& Primary school & $0(0)$ & $5(14.7)$ & $5(7.4)$ \\
& Junior high school & $2(5.9)$ & $3(8.8)$ & $5(7.4)$ \\
& Senior High School & $14(41.2)$ & $12(35.3)$ & $26(38.2)$ \\
& graduated from college & $16(47.1)$ & $13(38.2)$ & $29(42.6)$ \\
& Civil servants & $10(29.4)$ & $8(23.5)$ & $18(26.5)$ \\
& Employed & $7(20.6)$ & $10(29.4)$ & $17(25.0)$ \\
& Farmer & $0(0)$ & $1(2.9)$ & $1(1.5)$ \\
& Housewife & $12(35.3)$ & $13(38.2)$ & $25(36.8)$ \\
& Pensionary & $5(14.7)$ & $2(4.8)$ & $7(10.3)$ \\
\hline
\end{tabular}


Table 2. Socio-demographic characteristics of study participants in Kendari Municipality General Hospital From Rural Area South East Sulawesi Indonesia, 2018.

\begin{tabular}{|c|c|c|c|c|}
\hline \multicolumn{2}{|c|}{ Characteristics } & \multirow{2}{*}{$\frac{\text { Cases (\%) }}{1(2.9)}$} & \multirow{2}{*}{$\frac{\text { Controls }(\%)}{2(5.9)}$} & \multirow{2}{*}{$\frac{\text { Total }(\%)}{3(8.8)}$} \\
\hline Age & $26-35$ & & & \\
\hline & $36-45$ & $8 \quad(23.5)$ & $10(29.4)$ & $18(26.5)$ \\
\hline & $46-55$ & $10 \quad(29.4)$ & $9(13.2)$ & $19(55.9)$ \\
\hline & $56-65$ & $13(19.1)$ & $7(20.6)$ & $20(29.4)$ \\
\hline & $>65$ & $2(5.9)$ & $6(8.8)$ & $8 \quad(23.5)$ \\
\hline \multirow[t]{2}{*}{ Sex } & Male & $21(61.8)$ & $19(55.9)$ & $40(58.8)$ \\
\hline & Female & $13(38.2)$ & $15(44.1)$ & $28(41.2)$ \\
\hline \multirow[t]{6}{*}{ Educational status } & No School & $0(0)$ & $1(2.9)$ & $1(1.5)$ \\
\hline & Do not finish primary school & $2(5.9)$ & $1(2.9)$ & $3(4.4)$ \\
\hline & Primary school & $1(2.9)$ & $9(26.5)$ & $10(14.7)$ \\
\hline & Junior high school & $11(32.4)$ & $5(14.7)$ & $16(23.5)$ \\
\hline & Senior High School & $18(52.9)$ & $12(35.3)$ & $30(44.1)$ \\
\hline & graduated from college & $2(5.9)$ & $6(17.6)$ & $8(11.8)$ \\
\hline \multirow[t]{6}{*}{ Occupation } & Civil servants & $2(5.9)$ & $4(11.8)$ & $6(8.8)$ \\
\hline & Employed & $10(29.4)$ & $8(23.5)$ & $18(26.5)$ \\
\hline & Farmer & $8(23.5)$ & $10(29.4)$ & $18(26.5)$ \\
\hline & Fisherman & $0(0)$ & $2(5.9)$ & $2(2.9)$ \\
\hline & Housewife & $12(35.3)$ & $8(23.5)$ & $20(29.4)$ \\
\hline & Pensionary & $2(5.9)$ & $2(5.9)$ & $4(5.9)$ \\
\hline
\end{tabular}

\section{b. Sleep quality related to Type 2 Diabetes Mellitus}

Bivariate analysts showed that in urban communities, of the 68 respondents most of whom had poor sleep quality, 46 people $(67.6 \%)$. The statistical test shows a significant relationship (pv: 0.020, OR: 4,418, 95\% CI: 1,368-12,580). The same thing in rural communities from 68 respondents generally had poor quality sleep, which was 49 people (72.1 $\%$ ). Statistical tests show a significant relationship (pv: 0.031, OR: 4,060, 95\% CI: 1,26113,072) (Table 3).

\section{a. Sports activities related to Diabetes Mellitus Type 2}

Bivariate analysts showed that in urban communities, of the 68 respondents most of whom had low exercise activities, namely 36 people $(52.9 \%)$. The statistical test showed a significant relationship (pv: 0.029, OR: 3,378, 95\% CI: 1,246-9,157). The same thing in rural communities from 68 respondents generally had low exercise, which was 48 people $(70.6 \%)$. Statistical tests show a significant relationship (pv: 0.017, OR: 4,579, 95\% CI: 1,427-14,691). (Table 3) 
Table 3. Risk Factors For Sleep Quality And Sport Activity Against The Incidence Of Type 2 Diabetes Mellitus From Urban and Rural Areas In Kendari Municipality General Hospital South East Sulawesi Indonesia, 2018.

\begin{tabular}{|c|c|c|c|c|}
\hline \multirow{2}{*}{\multicolumn{2}{|c|}{ Urban }} & \multicolumn{2}{|c|}{ DM Type 2} & \multirow{2}{*}{ Total $(\%)$} \\
\hline & & Cases (\%) & Controls (\%) & \\
\hline \multirow[t]{3}{*}{ Sleep quality } & Bed & $28 \quad(82.4)$ & $18(52.9)$ & $46(67.6)$ \\
\hline & Good & $6 \quad(17.6)$ & $16(47.1)$ & $22(32.4)$ \\
\hline & & $P v(0.020)$ & OR(4.148) & 95\% CI (1.368-12.580) \\
\hline \multirow[t]{3}{*}{ Sport Activity } & Low & $23(67.6)$ & $13(38.2)$ & $36(52.9)$ \\
\hline & High & $11(32.4)$ & $21(61.8)$ & $32(47.1)$ \\
\hline & & $P v(0.029)$ & OR(3.378) & 95\% CI (1.246-9.157) \\
\hline \multicolumn{5}{|l|}{ Rural } \\
\hline \multirow[t]{3}{*}{ Sleep quality } & Bed & $29(85.3)$ & $20(58.8)$ & $49(72.1)$ \\
\hline & Good & $5(14.7)$ & $14(41.2)$ & $19(27.9)$ \\
\hline & & $P v(0.031)$ & OR(4.060) & 95\% CI (1.261-13.072) \\
\hline \multirow[t]{3}{*}{ Sport Activity } & Low & $29(85.3)$ & $19(55.9)$ & $48(70.6)$ \\
\hline & High & $5(14.7)$ & $15(44.1)$ & $20(29.4)$ \\
\hline & & $P v(0.017)$ & OR(4.579) & $95 \%$ CI (1.427-14.691) \\
\hline
\end{tabular}

\section{Discussions}

Sleep quality is a measure where a person can ease in starting to sleep and to maintain sleep, a person's sleep quality can be described by the length of sleep, and complaints that are felt during sleep or after waking up [14]. Sleep quality of urban and rural communities is generally ugly. Poor sleep quality in urban communities has a risk of 4.148 times and rural communities 4,060 times to suffer from type 2 diabetes compared to those who have good sleep quality.

The association between sleep and the occurrence of diabetes mellitus is associated with a disturbance in glucose tolerance. Sleep relations with blood glucose levels related to hormonal changes due to sympathetic nervous system activity and the hypothalamic-pituitary-andreal pathway that causes several hormones that can affect glucose tolerance and insulin resistance [15].

A decrease in glucose tolerance can occur during the sleep period. During the sleep period there can be an increase in blood glucose levels with an increase of around 20-30\% and an increase in maximal blood glucose levels occurs during mid-sleep. During the sleep period very few brain organs use glucose as energy and are characterized by a decrease in sympathetic nerve activity and an increase in vagal rhythms. Sleep is also associated with a strong increase in growth hormone levels when the activity of the pituitary gland and adrenal glands is inhibited [16].

In a study conducted by Evawisna (2018), it was shown that the majority of respondents had poor sleep breaks with $60 \%$ and $40 \%$ of respondents who had a good rest. People who have poor sleep rest are at risk of 2.33 or 2 times greater than respondents who have a good sleep rest in patients with type 2 diabetes mellitus [17].

The results showed that the majority of respondents who lived in urban and rural areas had poor sleep quality. This is due to problems that sometimes even interfere with sleep such as being unable to fall asleep while lying down, waking up in the middle of the night to the 
bathroom and other sleep disorders. As a result of frequent awakening, patients feel the need to rest less sleep. Respondents in this study were diabetics who also experienced insomnia. This is consistent with the opinion of Rodin (2008) that physical and psychological comorbidity is one of the epidemologies of insomnia. Diabetes mellitus is one of the comorbidities that triggers insomnia as a result of hormonal changes that trigger changes in the N-REM sleep phase 4. In addition, anxiety, mental disorders and the presence of pain also trigger sleep rest disorders. Based on the results of interviews with respondents, there is one interesting thing that makes their sleep quality worse, namely watching television. Respondents often ignore their nighttime sleep in order to watch television programs that they really like, so without realizing their sleep time is reduced [15].

Then, there are some respondents who live in urban and rural areas who have good sleep quality. This is because respondents sometimes never even experience problems that can interfere with sleep as perceived by respondents who have poor sleep quality. Respondents also assumed that their sleep quality was very good. Their sleep time is also sufficient and there is no burden of thought felt [16].

Significantly, someone who experiences constant sleep deprivation will make diabetes worse. A person suffering from type 2 diabetes mellitus has a $9 \%$ glucose level when he experiences lack of sleep. In addition, the level of insulin it has is $30 \%$ higher than when the sleep pattern is standard or sufficient, and insulin resistance is also higher to $43 \%$ [18].

Sleep quality is significant with the incidence of type 2 diabetes mellitus in communities in cities and rural areas. Factors that are closely related to this are behavior. The results of the research experts state that lack of sleep or lack of rest for three days can result in the body's ability to process glucose dramatically. That is, if someone experiences lack of sleep or lack of rest, the risk of Diabetes Mellitus will increase. In addition, lack of sleep can also stimulate a type of hormone in the blood that triggers appetite. Because, people with sleep disorders are usually encouraged to eat high-calorie foods because they are driven by hunger, thus making blood sugar levels rise. The solution, you should sleep no less than 6 hours a day, even better 8 hours a day [19].

Someone who suffers from Diabetes Mellitus, usually feels discomfort due to simptoms or signs and symptoms of the disease. Symptoms, such as: polyuria (a lot of urine), polidipsi (lots of drinking), poliphagi (lots of food) and others that occur at night can certainly interfere with sleep. The occurrence of sleep disturbances will have an impact on the increased frequency of awakening, difficulty falling asleep again, sleep dissatisfaction which ultimately results in a decrease in sleep quality [20].

Sports activity is a form of activity that is organized and planned that is beneficial to nourish the body which is done repeatedly by someone. Urban and rural community sports activities are generally low. Low exercise activities in urban communities have a risk of 3.378 times and rural communities 4,579 times to suffer from type 2 diabetes compared to those who have high sports activities.

Exercise causes insulin to increase so that blood sugar levels will decrease. In people who rarely exercise, food substances that enter the body are not burned but are buried in the body as dangula fat. If insulin is insufficient to convert glucose into energy DM will arise. After exercising, blood glucose will increase to 15 times the number of needs in normal circumstances [21]. Besides that, exercise also makes insulin work more effectively, helps to lose weight, strengthen the heart, and reduce stress [1] .

In a study conducted by Ikhtiyarotul Arofah in 2015, there was a significant relationship between exercise and the incidence of Type 2 diabetes. People who lack exercise risk 3,857 or 3 times greater than people who often exercise with type 2 diabetes mellitus [10]. 
The results showed that the majority of respondents who lived in urban and rural areas had low sports activities. This is because respondents are lazy to move and are busy with other activities so there is no time to exercise. The less exercise, the easier it is for someone to get diabetes mellitus. Exercise helps us to control weight. Blood glucose is burned into energy, and the body's cells become more sensitive to insulin. Blood circulation gets better, and the risk of type 2 diabetes mellitus will decrease to 50 percent [22].

Then there are some respondents who live in urban and rural areas who have high sports activities. This is because respondents regularly exercise every week. Sports are often carried out such as gymnastics, walking 30-45 minutes every morning, jogging, volleyball, badminton and soccer. Respondents were also aware of the importance of exercise on their health.

Sports activity is significant with the incidence of type 2 diabetes mellitus in communities in cities and rural areas. Factors that are closely related to this are behavior. At present, people still lack exercise activities. The community is more focused on emphasizing socio-economic conditions so that health conditions are neglected. Awareness of each person is needed to do this [23],[24].

Exercise that is highly recommended is aerobic exercise, such as walking, jogging, cycling, swimming. This type of exercise can improve health and fitness, and involve large muscles [25]. Exercise in people with diabetes mellitus can cause increased use of blood glucose by active muscles so that direct physical exercise can cause a decrease in body fat levels, control blood glucose levels, improve insulin sensitivity, reduce stress [26].

\section{Conclusions}

Sleep quality and exercise activity are risk factors for the incidence of type 2 diabetes mellitus in both patients from urban and rural areas in Southeast Sulawesi Indonesia. People are expected to exercise regularly and maintain the quality of their sleep to avoid diabetes mellitus.

\section{References}

[1] WHO, "Diabetes," Retrieved October 30, 2018, from http://www.who.int/news room/fact-sheets/detail/diabetes, 2018.

[2] WHO, "Noncommunicable diseases," Retrieved November 14, 2018, from http://www.who.int/news-room/fact-sheets/detail/noncommunicable-diseases, 2018.

[3] I. D. Federation, "Care and Prevention Diabetes and Cardiovascular Disease," Retrieved November 14, 2018, from https://idf.org/our-activities/care-prevention/cardiovasculardisease.html\#, 2016.

[4] I. D. Federation, "IDF Diabetes Atlas Eighth Edition 2017," 2017.

[5] M. o. H. Indonesia, Report on Results of National Basic Health Research 2013, National Institute of Health Research and Development MoH, Republic of Indonesia, Jakarta, 2013.

[6] M. o. H. Indonesia, Report on Results of National Basic Health Research 2018, National Institute of Health Research and Development MoH, Republic of Indonesia, Jakarta, 2018.

[7] S. E. S. H. Office, Health Profile of South East Sulawesi 2017, South East Sulawesi Health Office, 2018.

[8] M. H. o. o. Kendari, Health Profile of Kendari Municipality Municipality Health office of Kendari, 2018.

[9] S. Lemeshow, D. W. Hosmer, J. Klar, S. K. Lwanga, and W. H. Organization, 
"Adequacy of sample size in health studies,", 1990.

[10] I. Arofah, "Sports Relationship with Type II Diabetes Mellitus in the Purwosari Surakarta Health Center Working Area (Hubungan Antara Olahraga Dengan Kejadian DM Tipe II di Wilayah Kerja Puskesmas Purwosari.Surakarta)," Universitas Muhammadiyah Surakarta Surakarta, 2015.

[11] P. F. o. Australia, "Depression Anxiety Stress Scales (DASS). Australia Retrieved from http://www2.psy.unsw.edu.au/dass/,", 2018.

[12] U. o. Pittsburgh, "Pittsburgh Sleep Quality Index (PSQI) Pittsburgh. Retrieved from https://www.sleep.pitt.edu/research/instruments.html,", 2018.

[13] J. Burema, J. A. Baecke, and J. E. Frijters, "A short questionnaire for the measurement of habitual physical activity in epidemiological studies," The American Journal of Clinical Nutrition, vol. 36, no. 5, pp. 936-942, 1982.

[14] P. A. Potter, and A. G. Perry, "Buku ajar fundamental keperawatan: konsep, proses, dan praktik," Jakarta: Egc, vol. 1, 2005.

[15] L.-F. M. Taub, and N. S. Redeker, "Sleep disorders, glucose regulation, and type 2 diabetes," Biological research for nursing, vol. 9, no. 3, pp. 231-243, 2008.

[16] K. Spiegel, K. Knutson, R. Leproult, E. Tasali, and E. V. Cauter, "Sleep loss: a novel risk factor for insulin resistance and Type 2 diabetes," Journal of applied physiology, vol. 99, no. 5, pp. 2008-2019, 2005.

[17] E. Evaniswa, Y. Haskas, and K. Kartini, "Sleep Rest As a Risk Factor for Type II Diabetes Mellitus (DM) in the Labuang Baji Makassar Regional General Hospital (Istrahat Tidur Sebagai Faktor Risiko Kejadian Diabetes Melitus (DM) Tipe II di Ruamah Sakit Umum Daerah Labuang Baji Makassar)," Jurnal Ilmiah Kesehatan Diagnosis, vol. 12, no. 4, pp. 454-458, 2018.

[18] M. I. Jatinegara, Pola Hidup dan Tidur Sehat ala Rasullah Saw: Elex Media Komputindo, 2014

[19] L. A. Pramono, S. Setiati, P. Soewondo, I. Subekti, A. Adisasmita, N. Kodim, and B. Sutrisna, "Prevalence and predictors of undiagnosed diabetes mellitus in Indonesia," Age, vol. 46, no. 53.6, pp. 100.100, 2010.

[20] Z. P. Gustimigo, "Kualitas Tidur Penderita Diabetes Melitus," Jurnal Majority, vol. 4, no. 8, pp. 133-138, 2015.

[21] M. Asif, "The prevention and control the type-2 diabetes by changing lifestyle and dietary pattern," Journal of education and health promotion, vol. 3, 2014.

[22] H. Tandra, "Complete Guide to Know and Overcome Diabetes Quickly and Easily (Panduan Lengkap Mengenal dan Mengatasi Diabetes dengan Cepat dan Mudah)," Jakarta: Penerbit PT Gramedia Pustaka Utama, 2007.

[23] H. Cai, G. Li, P. Zhang, D. Xu, and L. Chen, "Effect of exercise on the quality of life in type 2 diabetes mellitus: a systematic review," Quality of Life Research, vol. 26, no. 3, pp. 515-530, 2017.

[24] A. D. Smith, A. Crippa, J. Woodcock, and S. Brage, "Physical activity and incident type 2 diabetes mellitus: a systematic review and dose-response meta-analysis of prospective cohort studies," Springer, 2016.

[25] P. E. Indonesia, "Management and Prevention of Type 2 Diabetes Mellitus in Indonesia (Pengelolaan dan Pencegahan Diabetes Melitus Tipe 2 di Indonesia)," PB. PERKENI, 2015.

[26] M. o. H. Indonesia, Info Datin: Condition and Analysis of Diabetes (SItuasi dan Analisis Diabetes) Ministry of Health Republic of Indonesia Center for Data and Information, Jakarta, 2014. 